\title{
UANG DALAM PANDANGAN ISLAM
}

\author{
Juliana \\ Universitas Pendidikan Indonesia \\ Jl. DR. Setibudi No. 229, Bandung. Indonesia \\ julian@upi.edu
}

\begin{abstract}
Abstrak
Penelitian ini dilatarbelakangi dengan bergulirnya konsep Gresham dan Fungsi turunan uang yang menyebabkan uang telah mengalami pergeseran dari fungsi aslinya. Tulisan ini bertujuan untuk mendeskripsikan sekaligus merekonstruksi fungsi uang dalam pandangan Islam. Metode yang digunakan dalam penilitian ini adalah kualitatif dengan menggunakan literur review yang di ambil dari beberapa buku dan sumber bacaan yang relevan. Adapun hasil penelitian ini menyatakan bahwa dengan adanya teori Grasham, menyebabkan uang "baik" hilang dan tergantikan oleh uang yang "jelek". Hal ini berkorelasi dengan adanya fungsi turunan uang yang berdampak uang "baik" lebih banyak di timbun dan tidak beredar di masyarakat. Adapun perspektif Islam, aktivitas menimbun uang tidak dibenarkan dan bertentangan dengan dalil syara. Adapun fungsi uang hanya dua yaitu, satuan hitung dan sebagai alat tukar aktivitas.
\end{abstract}

\section{Keyword: Teori Gresham, Fungsi Uang, Menimbun Emas, Uang Emas dan Perak}

\begin{abstract}
This research is motivated by the rolling of the Gresham concept and the derivative function of money that causes the money to have shifted from its original function. This paper aims to describe as well as reconstruct the function of money in the view of Islam. The method used in this research is qualitative by using a review literature taken from several books and relevant reading sources. The results of this study states that with the theory of Grasham, cause money "good" lost and replaced by money "bad". This is correlated with the existence of a money derivative function that affects "good" money more in heap and does not circulate in the community. As for the Islamic perspective, the accumulation of money is not justified and contrary to the argument of syara. The function of money only two that is, unit count and as a tool of activity exchange.
\end{abstract}

\section{Keyword: Gresham Theory, Money Function, Stockpiling of gold, Gold and Silver Money}

\section{PENDAHULUAN}

Dalam sistem ekonomi, keberadaan uang merupakan hasil inovasi besar dalam evolusi perekonomian dunia. Sebagai salah satu bagian variabel penting dalam perekonomian, maka posisi uang dipandang sangat strategis fungsinya di dalam sebuah bingkai sistem ekonomi dan sulit untuk diganti dengan variabel lain. Oleh karena itu, uang merupakan bagian suatu fungsi yang terintegrasi dalam suatu perekonomian. Uang merupakan bagian yang tidak dapat dipisahkan dalam suatu sistem ekonomi modern (Pujiyono, 2004) 
Begitupun dalam sistem ekonomi modern saat ini, uang merupakan media tukar yang dapat memperlancar proses berputarnya roda pembangunan ekonomi. Uang memungkinkan perdagangan dan transaksi ekonomi dapat dilaksanakan secara efisien, sehingga dapat mencapai tingkat spesialisasi optimum dengan disertai peningkatan produktifitas. Dalam proses perkembangannya, penggunaan uang kertas merupakan evolusi yang sangat fondamental dalam perekonomian. Tulisan ini bertujuan untuk memberikan kajian kritis terhadap teori Grasham serta telaah pustaka tentang dinar sebagai sistem standar tunggal emas ditinjau menurut sistem moneter Islam.

Menurut (Pujiyono, 2004) dalam tulisannya yang berjudul Sistem Standar Tunggal Emas bagi Negara Mayoritas Muslim dalam Sistem Ekonomi Global menyatakan bahwa Uang adalah timbangan atas nilai suatu barang, yang identik dengan fungsi uang sebagai alat pengukur nilai. Lebih lanjut dia mengatakan bahwa sebagai pengukur nilai, uang seharusnya memiliki standar ukur yang benar.

Dalam Al-Quran sendiri dijelaskan "Dan sempurnakanlah takaran dan timbangan dengan adil" (Al-An' Am : 152). Uang sebagai penyimpan nilai diharapkan juga mampu berbuat adil dalam pembayaran tunda, kerena usaha yang dilakukan saat ini tidak ada kepastian di masa depan, 'Dan tiada seorangpun yang dapat mengetahui secara pasti apa yang akan diusahakannya' (QS. Luqman: 34). Meski demikian, risk return profile tetap dilakukan dengan analisa rasional ekonomi, bukan sebagaimana mekanisme yang telah ditetapkan melalui tingkat bunga tetap (fixed rate). Adanya fluktuasi dan ketidakstabilan uang kertas dengan sistem bunga inilah yang membedakannya dengan uang emas sebagai standar moneter.

Dalam sejarah komoditi uang sebagai standar, terdapat dua standar yang umum digunakan yaitu standar emas (gold currency standards) dan standar perak (silver currency standards). Meski demikian secara umum dapat didefinisikan sebagai satuan moneter dari emas dengan ukuran tertentu terhadap satu satuan mata uang (termasuk perak) dan mendapat ijin penuh dalam mengkonversi antara emas dengan uang dan antara uang dengan emas. Hubungan mekanis emas dan satuan moneter jelas akan mendorong keyakinan akan nilai unit moneter. Hal inilah yang menjamin stabilitas terhadap sistem moneter.

Berbicara terkait uang emas atau dalam hal ini penulis sebut dengan Dinar, maka menimbulkan polemik pro dan 
kontra dikalangan masyarakat khususnya para akademisi. Hal ini sangat wajar terjadi karena disebabkan diantara masyarakat ada yang menggunakan sudut pandang ekonomi yang cenderung berbeda, namun disatu sisi tidak sedikit dari masyarakat khususnya para intelektual muslim menggunakan sudut pandangan ekonomi Islam. Bahkan yang menarik lagi adalah bagi intelektual dan pakar ekonomi barat sendiri yang objektif melihat bahwa terkait penggunaan emas adalah sistem moneter paling baik yang lebih stabil dan tahan terhadap inflasi.

Hal ini sesuai pernyataan Alan Greenspan (mantan Chairman The Fed), "Emas masih menjadi bentuk utama pembayaran di dunia. Dalam kondisi ekstrem, tidak ada yang mau menerima uang fiat. Tapi emas selalu diterima”. Begitupun menurut Cristopher Wood, seorang analis Emerging Market CLSA, mengatakan "Emas adalah satu-satunya jaminan nyata terhadap ekses-ekses keuangan massif yang masih dirasakan dunia Barat. Wood juga mengatakan ketika nilai tukar dolar anjlok, harga emas akan terus naik”. Hal yang sama disampaikan Robert Mundell, penerima nobel ekonomi memperkirakan bahwa emas akan kembali menjadi bagian system keuangan internasional pada abad ke-21 (Hamidi, 2007).
Tidak beda jauh, Peter Bernstein seorang pakar keuangan terkemuka dunia mengatakan secara terbuka bahwa: "Gold is the ultimate certainly and escape from risk”. Ketika semua mata uang kertas berjatuhan, emas akan menunjukkan kesaktiannya. Ketika fiat money satu persatu berjatuhan, emas (Dinar) menunjukkan nilai yang stabil dan cenderung menguat terhadap mata uang kertas. Ungkapan senada juga dilontarkan oleh Jerome F Smith "As fewer and fewer people have confidence in paper as store of value, the price of gold will continue to rise".

(Hamidi, 2007) menjelaskan bahwa sejarah membuktikan emas bisa menjelma manjadi mata uang yang sangat stabil dibanding banding mata uang kertas (fiat money) manapun, termasuk dolar. Pada tahun 1800 harga emas persatu troy ons setara dengan 19,39 dolar AS, sementara tahun 2004, satu troy ons emas senilai 455,757. Dengan kata lain selama dua abad berlalu, emas mengalami apresiasi yang luar biasa sebesar 2.250 persen terhadap dolar".

Dari pemaparan diatas terlihat bahwa emas merupakan solusi fundamental terhadap sistem moneter international. Namun semua paparan diatas nyaris terbantahkan akibat dari konsep atau teori Gresham yang menyatakan "bad money 
out drive good money". Teori ini menjelaskan bahwa uang baik akan tergantikan oleh uang yang jelak. Menurut sudut pandang penulis uang emas dan perak atau dinar dan dirham dapat digolongkan terhadap uang baik. sebaliknya uang kertas (fiat money) menurut menulis merupakan uang yang jelak. Maka berdasarkan teori Gresham tersebut uang emas dan perak pasti tergantikan oleh uang kertas.

Asumsi ini terjadi ketika, mata uang fiat money dan uang emas beredar secara bersamaan. Maka yang terjadi adalah uang emas akan terkalahkan oleh fiat money, karena uang baik (emas) akan banyak ditimbun dan pada akhirnya yang akan beredar di masyarakat adalah uang jelek atau uang kertas. Hal inilah yang menjadi salah satu penghambat penerapan sistem mata uang emas. Mereka menempatkan emas lebih banyak untuk di simpan dan sebagai penimbun kekayaan. Ini akibat dari fungsi turunan uang menempatkan fungsi emas sebagai fungsi "Store of Value" atau penyimpan kekayaan.

Kenyataan di atas, jika dirunut lebih jauh, berpangkal dari pergeseran fungsi uang itu sendiri. Uang sudah sedemikian jauh meninggalkan fungsinya aslinya dan menemukan fungsi-fungsi baru yang sebenarnya tidak berakar dari watak aslinya. Motif ekonomi untuk meraih keuntungan tanpa batas dengan meminimalisir resiko serendah mungkin telah menjebak para pelaku ekonomi untuk memposisikan uang pada tempat yang salah. Dampak yang nyata dari hal tersebut sudah jelas, semakin mudah timbulnya gejolak ekonomi yang melanda negaranegara dengan basis ekonomi dan politik yang lemah, tidak terkecuali Indonesia.

\section{PEMBAHASAN}

\section{A. Konsep Uang}

Banyak ekonom yang telah mendefinisikan uang, salah satu diantaranya menurut A.C.Pigau, dalam bukunya: "The Veil of Money", dia menejelaskan "Money are those things that are widely used as a media for exchange". Dengan kata lain, uang menurutnya adalah segala sesuatu yang umum dipergunakan sebagai alat penukar (Manulang, 1993: 13). Adapun Robertson dalam bukunya: "Money", menjelaskan bahwa "Money is something wich is widely accepted in payments for goods", yaitu segala sesuatu yang umum diterima dalam pembayaran barang-barang (Suparmono, 1990).

Berdasarkan definisi-definisi di atas, dapat disimpulkan bahwa uang adalah segala sesuatu yang umum diterima sebagai alat penukar dan sebagai alat pengukur nilai, yang pada waktu yang bersamaan bertindak sebagai alat 
penimbun kekayaan” (Manullang, 1993).

Dengan adanya uang, mampu menyediakan alternatif transaksi yang lebih mudah daripada barter dan cocok digunakan dalam sistem ekonomi modern. Selain itu, keberadaan uang mampu menciptakan Efisiensi, karena uang pada akhirnya akan mendorong perdagangan dan pembagian tenaga kerja yang kemudian akan meningkatkan produktifitas dan kemakmuran.

\section{B. Fungsi Uang}

Secara umum, uang memiliki fungsi sebagai perantara untuk pertukaran barang dengan barang, juga untuk menghindarkan perdagangan dengan cara barter. Secara lebih rinci, fungsi uang dibedakan menjadi dua: fungsi asli dan fungsi turunan. Fungsi asli uang ada dua, yaitu sebagai alat tukar dan sebagai satuan hitung.Uang berfungsi sebagai alat tukar atau medium of exchange yang dapat mempermudah pertukaran. Orang yang akan melakukan pertukaran tidak perlu menukarkan dengan barang, tetapi cukup menggunakan uang sebagai alat tukar. Kesulitan-kesulitan pertukaran dengan cara barter dapat diatasi dengan pertukaran uang.

Uang juga berfungsi sebagai satuan hitung (unit of account) karena uang dapat digunakan untuk menunjukan nilai berbagai macam barang/jasa yang diperjualbelikan, menunjukkan besarnya kekayaan, dan menghitung besar kecilnya pinjaman. Uang juga dipakai untuk menentukan harga barang/jasa (alat penunjuk harga). Sebagai alat satuan hitung, uang berperan untuk memperlancar pertukaran.

Menurut Keynesian uang bukan hanya sebagai alat transaksi, tetapi juga sebagai penyimpan nilai. Fungsi penyimpan nilai inilah yang memungkinkan uang di gunakan sebagai alat memperoleh keuntungan, melalui fungsi turunan lainya seperti spekulasi, penimbun kekayaan. pemindah kekayaan (modal), alat untuk meningkatkan status sosial dan berjaga-jaga. Karena itu uang tidak bersifat netral.

\section{Konsep dan Teori Gresham}

Menurut kamus Bank Indonesia teori Gresham mengatakan bahwa orang cenderung menggunakan uang lusuh (jelek) sehingga akan mengakibatkan uang yang masih baik keluar dari peredaran; misalnya, apabila terdapat dua macam mata uang yang nominalnya sama, seseorang akan terdorong untuk menahan uang yang baik dan menggunakan yang lusuh (gresham law).

Uang "bagus" adalah uang yang menunjukkan sedikit perbedaan antara nilai nominal (nilai nominal koin) serta 
nilai komoditas (nilai dari logam yang dibuat, seperti logam mulia, nikel, atau tembaga) Di sisi lain, uang "buruk" adalah uang yang memiliki nilai komoditas yang jauh lebih rendah dari nilai nominalnya dan beredar bersama dengan uang yang baik, dimana kedua bentuknya diperlukan untuk dapat diterima pada nilai yang sama sebagai legal tender.

Ketika tidak seorangpun yang menginginkan penurunan nilai uang logam, yang terbuat dari logam lebih murah dibandingkan dengan mata uang logam yang telah beredar, setiap orang berupaya untuk menukarkan uang "buruk" ini dan dalam waktu yang sama menyimpan uang "bagus". Dengan demikian, koin-koin yang lebih baik mutunya, tidak lagi beredar dan koin-koin yang lebih rendah kualitasnya yang dipakai sebagai alat untuk nilai pertukaran komersial inilah yang melatar belakangi lahirnya “Gresham Law" pada tahun 1858 di Inggris.

\section{Uang Emas dalam Pandangan Ekonomi Islam}

Fungsi turunan uang mengakibatkan uang menjadi objek komoditas dan penimbun kekayaan yang bisa di jual belikan serta dapat di timbun. Sebagai salah satu efek dari fungsi turunan tersebut yaitu adanya penimbunan emas. Padahal penimbunan uang adalah salah satu bentuk keharaman bagi seorang muslim. Hal ini sesuai dengan salah satu firman Allah dalam Al Quran surat At Taubah ayat 34. Maksud dari ayat tersebut adalah adanya ancaman berupa siksaan yang pedih atas orang yang menimbun emas dan perak merupakan qarinah (indikasi) yang menunjukkan bahwa larangan itu bersifat tegas (jazim). Dengan demikian, menimbun emas dan perak hukumnya haram. Keharaman itu bersifat pasti dan umum.

Untuk itu,dalam tulisan secara tidak langsung mengajak kembali kepada fungsi uang yang sebenarnya yang telah dijalankan dalam konsep Islam, yakni sebagai alat pertukaran dan satuan nilai, bukan sebagai penimbun kekayaan. Harus disadari bahwa sesungguhnya uang itu hanyalah sebagai perantara untuk menjadikan suatu barang kepada barang yang lain.

An Nabhani menyatakan Islam telah memberikan kebebasan kepada manusia untuk melakukan pertukaran dengan mempergunakan apa saja yang dia sukai. Hanya saja, pertukaran barang dengan satuan uang tertentu itu telah ditunjukkan oleh Islam satu sistem moneter. Dan Islam telah menetapkan bagi kaum muslimin kepada jenis tertentu yaitu emas dan perak. Kesimpulan ini berdasarkan 
beberapa alasan berikut ( An-Nabhani, 1990) :

1. Islam mengharamkan menimbun (al kanz) emas dan perak larangan pada Al Quran surat At-Taubah ayat 34 di tertuju pada penimbunan emas dan perak, sebagai emas dan perak, dan sebagai mata uang dan alat tukar.

2. Islam telah mengaitkan emas dan perak dengan hukum-hukum yang baku, seperti diyat dalam pembunuhan sebesar 1000 dinar dan batasan bagi potong tangan atas pencurian atas harta yang mencapai $1 / 4$ dinar.

3. Rasulullah SAW telah menetapkan emas dan perak sebagai mata uang, dan menjadikan hanya emas dan perak sajalah sebagai standar uang. Dimana standar barang dan jasa akan dikembalikan kepada standar tersebut.

4. Ketika Allah SWT mewajibkan zakat uang, maka Allah telah mewajibkan zakat tersebut untuk emas dan perak, kemudian Allah menentukan nishab zakat tersebut dengan nishab emas dan perak.

5. Ketika Islam menetapkan hukum pertukaran uang (sharf), Islam menetapkan uang dalam bentuk emas dan perak. Sharf adalah menukarkan atau membeli uang dengan uang, baik dalam jenis yang sama seperti membeli emas dengan emas atau perak dengan perak, maupun antar jenis yang berbeda seperti membeli emas dengan perak.

\section{E. Fungsi Uang dalam pandangan Ulama}

Konsep Gresham, jauh sebelumnya sudah disinggung oleh seorang ulama yang bernama Ibnu Taimiyah. Ibnu Taimiyah menyatakan bahwa uang yang buruk akan menyingkirkan uang yang berkualitas baik dari peredaran, leboh jelasnya Ibnu Taimiyah menyatakan apabila penguasa membatalkan penggunaan mata uang tertentu dan mencetak jenis mata uang yang lain bagi masyarakat, hal ini akan merugikan orang-orang kaya yang memiliki uang karena jatuhnya nilai uang lama menjadi hanya sebuah barang. Ia berarti telah melakukan kedzaliman karena menghilangkan nilai tinggi yang semula mereka miliki. Lebih daripada itu, apabila nilai intrinsik mata uang tersebut berbeda, hal ini akan menjadi sebuat sumber keuntungan bagi para penjahat untuk mengumpulkan mata uang yang buruk dan menukarnya dengan mata uang yang baik dan kemudian mereka akan membawwanya ke daerah lain dan menukarkannya dengan mata uang yang buruk di daerah tersebut untuk dibawa kembali ke daerahnya. Dengan demikian, nilai barang masyarakat akanmenjadi hancur (Amalia, 2010). 
Pada pernyataan diatas, Ibnu Taimiya menyebutkan akibat yang akan terjadi atas masuknya nilai mata uang yang buruk bagi masyarakat yang sudah terlanjur memilikinya. Jika mata uang tersebut kemudian dinyatakan tidak berlaku lagi sebagai mata uang, berarti hanya akan diperlakukan sebagai barang biasa yang tidak memiliki nilai yang sama dibandingkan dengan ketika berfungsi sebagai mata uang. Disisi lain, seiring dengan kehadiran mata uang yang baru, masyarakat akan memperoleh harga yang lebih rendah untuk barang-barang mereka (Amalia, 2010)

Lebih jauh Ibnu Taimiyah menyebutkan dua fungsi utama uang yaitu sebagai pengukur nilai dan media pertukaran bagi sejumlah barang yang berbeda. Ia menyatakan "atsman" (harga atau yang dibayarkan sebagai harga, yaitu uang) dimaksudkan sebagai pengukur nilai barang-barang (mi'yar al-amwal) yang dengan jumlah nilai barang-barang (maqodir al-amwal) dapat diketahui; dan uang tidak pernah dimaksudkan untuk diri mereka sendiri.

Berdasarkan pandangannya Ibnu Taimiyah menentang keras segala bentuk perdagangan uang, karena hal ini mengalihkan fungsi uang dari tujuan yang sebenarnya. Apabila dua orang saling mempertukarkan uang dengan kondisi satu pihak membayar tunai sementara pihak lainnya berjanji membayar dikemudian hari, kemudian pihak yang pertama tidak akan bisa menggunakan uang yang dijanjikan untuk bertransaksi sampai uang tersebut dibayar, hal ini berarti pihak pertama telah kehilangan kesempatannya (Amalia, 2010).

Adapun menurut AL Ghazali memiliki pandang yang khas mengenai uang, hal itu di tulisnya pada bab asSyukru, dalam kitab Ihya 'Ulumuddin. AlGhazali membicarakan masalah uang yang digunakan manusia sebagai nikmat dari Allah SWT, dengan sistem transaksi Barter. $^{43}$ Lebih jauh Al Ghazali menjelaskan uang sebagai sesuatu yang penting dalam peraturan bisnis, menurutnya, karena uang merupakan salah satu nikmat Allah yang harus ditempatkan sesuai dengan aturan-aturan-Nya (AlGhazali).

Lebih jelasnya lagi kata al-Ghazali, uang (baca: dinar dan dirham) adalah Khadimani wa la khadimun la huma wa muradani wa la yuradani, (alat untuk mencapai suatu maksud, yakni sebagai suatu alat perantara saja dan tidak untuk yang lain). Dengan demikian, maka definisi yang dikemukakan al-Ghazali semakna dengan definisi-definisi lainnya. Akan tetapi diakui bahwa signifikansi argumentasi dalam definisi yang 
dikemukakan al-Ghazali adalah bahwa uang ternyata hanya sebagai alat tukar (Unit of Exchange) dan penengah (Interdemiary) saja yang selanjutnya dalam perekonomian modern uang sangat penting dalam peraturan bisnis baik regional maupun internasional (AlGhazali).

Menurut al-Ghazali, ada dua fungsi uang yang membuat orang dapat mudah memanfaatkannya. Pertama, Allah SWT. Menjadikan (mata uang) dinar dan dirham, sebagai hakim dan dua penengah (Double justice and coincident), diantara harta benda-benda lain-lainnya. Sehingga dapat dipastikan harta benda itu dengan dinar dan dirham. Kedua, keduanya (dinar dan dirham) itu menjadi perantara kepada barang-barang yang lainnya (medium of exchange for goods and service) (Mardiana, 2014).

Dalam konsep ekonomi Islam, uang adalah uang, bukan capital, sementara dalam konsep ekonomi konvensional, konsep uang tidak begitu jelas, misalnya dalam buku "Money, Interest and Capital" karya Colin Rogers, uang diartikan sebagai uang dan capital secara bergantian, sedangkan dalam konsep ekonomi Islam uang adalah sesuatu yang bersifat flow concept dan merupakan public goods, sedangkan capital bersifat stock concept dan merupakan private goods. Uang yang mengalir adalah public goods, sedangkan yang mengendap merupakan milik seseorang dan menjadi milik pribadi (private good).

Islam telah lebih dahulu mengenal konsep public goods, sedangkan dalam ekonomi konvensional konsep tersebut baru dikenal pada tahun 1980-an seiring dengan berkembangnya ilmu ekonomi lingkungan yang banyak membicarakan masalah externalities, public goods dan sebagainya. Konsep public goods tercermin dalam sabda Rasulullah SAW, yakni "Tidaklah kalian berserikat dalam tiga hal, kecuali air, api, dan rumput."

Persamaan fungsi uang dalam sistem ekonomi Islam dan konvensional adalah uang sebagai alat pertukaran (medium of exchange) dan satuan nilai (unit of account), sedangkan perbedaannya ekonomi konvensional menambah satu fungsi lagi sebagai penyimpan nilai (store of value) yang kemudian berkembang menjadi "motif money demand for speculation" yang merubah fungsi uang sebagai salah satu komoditi perdagangan. Padahal jauh sebelumnya, Imam alGhazali telah memperingatkan bahwa "Memperdagangkan uang ibarat memenjarakan fungsi uang, jika banyak uang yang diperdagangkan, niscaya tinggal sedikit uang yang dapat berfungsi sebagai uang." 
Dengan demikian, dalam konsep Islam, uang tidak termasuk dalam fungsi utilitas karena manfaat yang kita dapatkan bukan dari uang itu secara langsung, melainkan dari fungsinya sebagai perantara untuk mengubah suatu barang menjadi barang yang lain. Dampak berubahnya fungsi uang dari sebagai alat tukar dan satuan nilai mejadi komoditi dapat kita rasakan sekarang, yang dikenal dengan teori "Bubble Gum Economic”.

\section{F. Menimbun Emas dalam Pandangan Ekonomi Islam}
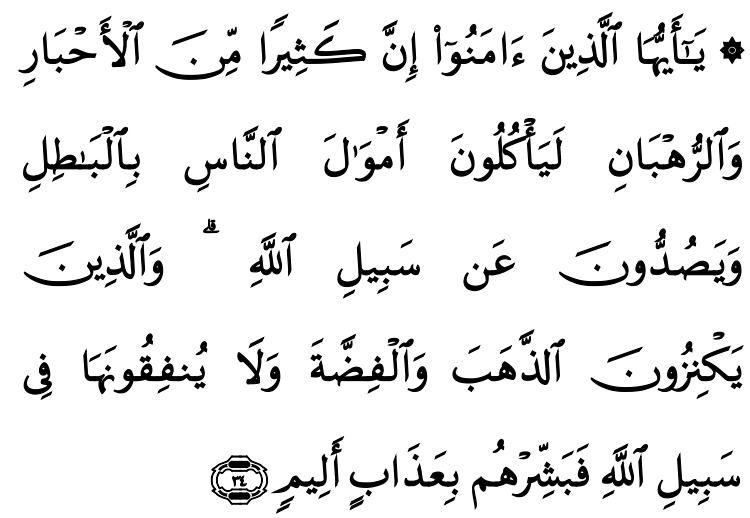

Artinya:

"Hai orang-orang yang beriman, Sesungguhnya sebahagian besar dari orang-orang alim Yahudi dan rahib-rahib Nasrani benar-benar memakan harta orang dengan jalan batil dan mereka menghalang-halangi (manusia) dari jalan Allah. dan orang-orang yang menyimpan emas dan perak dan tidak menafkahkannya pada jalan Allah, Maka beritahukanlah kepada mereka, (bahwa mereka akan mendapat) siksa yang pedih.(QS At Taubah: 34”)

Menurut Yahya Abdurrahman selaku ahli tafsir mengatakan bahwa maksud dari ayat tersebut adalah adanya ancaman berupa siksaan yang pedih atas orang yang menimbun emas dan perak merupakan qarinah (indikasi) yang menunjukkan bahwa larangan itu bersifat tegas (jazim). Dengan demikian, menimbun emas dan perak hukumnya haram. Keharaman itu bersifat pasti dan umum, alasannya:

Pertama: ayat ini bersifat umum berlaku untuk semua penimbunan emas dan perak. Keharaman menimbun emas dan perak dalam ayat ini ditunjukkan dengan penunjukan yang pasti. Penerapan larangan menimbun dalam ayat ini hanya untuk emas dan perak yang tidak dikeluarkan zakatnya, atau dengan kata lain membolehkan penimbunan emas dan perak setelah dikeluarkan zakatnya, memerlukan adanya nash lain yang memalingkan larangan dalam ayat ini atau yang me-nasakh-nya. Padahal tidak terdapat nash yang memalingkannya atau me-nasakh-nya. Adapun riwayat yang menyatakan bahwa emas dan perak yang dikumpulkan baik yang dipendam atau tidak, jika dikeluarkan zakatnya tidak termasuk penimbunan yang dilarang, semuanya bukanlah hadis yang sahih. Sebabnya, riwayat-riwayat itu adalah 
riwayat mawqaf, yakni sanad-nya berhenti pada Sahabat dan tidak sampai kepada Nabi saw.

Kedua: ath-Thabari meriwayatkan berturut-turut dari: al-Hasan, Abd arRazaq, Mamar dari Qatadah, Syahr bin Hawsyab dari Abu Umamah bahwa ia berkata: Seorang laki-laki dari kalangan Ahlush Shuffah meninggal dunia. Di sakunya terdapat uang satu dinar. Rasulullah saw. bersabda, Kayyah (satu stempel dari api). Kemudian seorang Ahlush Shuffah yang lain meninggal dunia dan di sakunya terdapat dua dinar. Rasulullah saw bersabda, Kayyatn (Dua stempel dari api).

Imam Ahmad meriwayatkannya dari Ali bin Abi Thalib dan Ibn Mas'ud. Hal itu karena keduanya adalah orang yang hidup dari sedekah, sementara keduanya memiliki emas. Sabda Rasul saw, kayyah dan kayyatan, itu mengisyaratkan pada larangan menimbun emas dan perak di atas. Sabda Rasul itu juga mengisyaratkan bahwa keduanya telah menimbun emas. Hal itu karena keduanya adalah Ahlush Shuffah yang kehidupannya telah dipenuhi dari harta sedekah (zakat). Itu menandakan bahwa keduanya menyimpan emas tersebut bukan dalam rangka menabung karena kehidupannya telah dijamin dari shadaqah. Jumlah satu dan dua dinar jelas belum memenuhi nishab zakat. Ini menunjukkan bahwa penimbunan emas dan perak yang terkena ancaman ayat di atas bukan hanya dalam jumlah yang sudah mencapai nishab dan tidak dikeluarkan zakatnya. Setiap penimbunan emas dan perak berapapun terkena ancaman ayat di atas dan hukumnya haram, meski hanya satu atau dua dinar.

Ketiga: ancaman ayat di atas terkait dengan dua macam aktivitas: aktivitas menimbun emas dan perak; dan aktivitas tidak membelan-jakannya di jalan Allah. Artinya, ada orang yang tidak menimbun emas dan perak tetapi tidak membelanjakannya di jalan Allah; orang yang menimbun emas dan perak dan tidak membelanjakannya di jalan Allah; dan orang yang menimbun emas dan perak saja meski ia membelanjakan sebagian hartanya di jalan Allah. Semuanya terkena ancaman ayat di atas. Al-Qurthubi mengatakan di dalam tafsirnya, Siapa yang tidak menimbun, sementara ia menahan pembelanjaanya di jalan Allah, ia mesti demikian juga (terkena ancaman ayat tersebut). Frasa di jalan Allah ( $f i$ sabilillah) di dalam al-Quran, jika dikaitkan dengan infak, maksudnya adalah jihad fi sabilillah, bukan yang lain.

Keempat: Imam Bukhari meriwayatkan dari Zaid bin Wahab tentang perbedaan pendapat Muawiyah bin Abi Sufyan dengan Abu Dzar tentang ayat 
di atas. Muawiyah berkata, Ayat ini bukan untuk kita, melainkan ayat ini hanya untuk Ahlul Kitab. Abu Dzar membantah dengan mengatakan, Sungguh, ayat ini untuk kita dan mereka. Muawiyah lalu melaporkan Abu Dazar kepada Khalifah Utsman. Lalu Khalifah memanggil Abu Dazar ke Madinah, dan berlangsunglah peristiwa seperti yang diceritakan dalam riwayat tersebut. Perbedaan pendapat yang terjadi antara Muawiyah dan Abu Dzar adalah untuk siapa ayat tersebut diturunkan. Seandainya saat itu sudah masyhur riwayat dari Nabi saw. bahwa emas dan perak yang telah dikeluarkan zakatnya tidak termasuk al-kanzu, tentu Muawiyah akan ber-hujjah dengannya dan Abu Dzar pun akan diam karenanya. Namun, sampai ketika Abu Dzar menghadap Khalifah Utsman sekalipun, tidak disampaikan riwayat itu meski banyak dari Sahabat yang masih tinggal di Madinah.

Kelima: Kanzu adz-dzahab wa alfidhah secara bahasa maknanya mengumpulkan /menimbun emas dan perak dan menyimpannya baik di dalam tanah maupun di atas tanah. Lafal al-Quran dimaknai dengan makna bahasanya saja, kecuali terdapat makna syariah yang dinyatakan oleh nash; dalam kondisi tersebut makna syariah dikedepankan atas makna bahasa. Lafal al-kanzu tidak terdapat makna syariahnya. Karena itu, lafal ini dalam ayat di atas harus dimaknai menurut makna bahasanya saja.

Dengan demikian, kanzu adzdzahab wa al-fidhah (menimbun emas dan perak) atau menimbun uang adalah mengumpulkannya dan menyimpannya baik di dalam tanah maupun di atas tanah. Hal itu dilakukan semata untuk mengumpulkan dan menyimpannya saja, bukan untuk menabung dalam rangka membiayai suatu keperluan yang direncanakan. Semua bentuk penimbunan emas dan perak atau penimbunan uang itu hukumnya haram dan pelakunya diancam dengan siksaan yang amat pedih di akhriat kelak.

\section{SIMPULAN}

Konsep Gresham berdampak signifikan terhadap "hilangnya" uang baik. Selain itu adanya fungsi turunan uang mengakibatkan uang menjadi objek komoditas dan penimbun kekayaan. Sebagai salah satu efek dari fungsi turunan tersebut yaitu adanya penimbunan emas. Padahal aktivitas menimbun emas dan perak merupakan aktivitas yang dilarang dalam Islam karena hal ini akan merugikan banyak pihak. Salah satu ayat dalam Al Quran yaitu surat At-Taubah ayat 34 secara jelas menegaskan bahwa bagi yang menimbun emas maka balasannya siksa yang sangat pedih. Dengan demikian, 
menimbun emas dan perak hukumnya haram. Fungsi uang yang sebenarnya yang telah dijalankan dalam konsep Islam, yakni sebagai alat pertukaran dan satuan

\section{Daftar Pustaka}

Abdurahman Yahya. Hukum Menimbun Emas dalam Islam. Jurnal Ekonomi Ideologis

Al-Ghazali, A. H. (n.d.). Ihya 'Ulum alDin. Beirut: Dar Al-Nadwah.

Amalia, E. (2010). Sejarah Pemikiran Ekonomi Islam. Depok: Gramata Publishing.

An-Nabhani, T. (1990). Nidzamul Iqtishadi Fil Islam. Daarul Ummah.

Al-Quran dan Al-Hadist

Al-'Assal, A.M dan Fathi Ahmad Abdul Karim, 1999, Sistem, Prinsip dan Tujuan Ekonomi Islam (Terjemahan), Penerbit CV. Pustaka Setia.

Al-Maliki, A., As-Siyasah Al-Iqtishadiyah Al-Mutsla, Penerbit Hizb AtTahrir. Bairut. 1953.

Chapra, Umar, Sistem Moneter Islam, Jakarta: Gema Insani Pres.

Dudik, Analisis Pengunaan Emas Sebagai Mata Uang Dinar Studi Kasus di Indonesia, Jurnal IFSIED, 2002. nilai, bukan sebagai komoditi dan spekulatif. Uang sesungguhnya sebagai perantara untuk menjadikan suatu barang kepada barang yang lain.

Faiz Abbu (penerjeah), Menyongsong Sistem Ekonomi Anti Krisis.

Pustaka Thaikul Izzah. Bogor, 2009.

Hamidi, L. (2007). Gold Dinar Sistem Moneter Global Yang Stabil dan Berkeadilan. Jakarta: Senayan Publising.

Manullang. (1993). Ekonomi Moneter. Jakarta: Ghalia Indonesia.

Mardiana, A. (2014). Uang Dalam Ekonomi Islam. Jurnal Al-Buhuts, Vol 10 No 1.

Merza, Gamal, Perspektif Uang Islami. www.ekonomisyariah.net

Nopirin, Ekonomi Moneter, Yogyakarta: BPFE, 1992

Pujiyono, A. (2004). Dinar Dan Sistem Standar Tunggal Emas Ditinjau Menurut Sistem Moneter Islam. Jurnal.

Suparmono. (1990). Pengantar Ekonomi Makro. Yogyakarta: BPFE.

Yusanto, Ismail, Pengantar Sistem Ekonomi Islam, Bogor: Al Azhar Pres, 2009, 
Juliana, Uang Dalam Pandangan Islam

Zallum, Abdul Qadim, al-Amwal $f i$

Daulatil Khilafah. Dar al ilmi

lilmalayin. Beirut, 2004. 